\title{
The Role of the Kinship System in Social Conflict Resolvment in Indigenous People of KEI
}

\author{
Priyo Subekti ${ }^{1}$, Heru Ryanto Budiana ${ }^{2}$, Pawit Muhammad Yusup ${ }^{3}$ \\ Faculty of Communication Science, Padjadjaran University, Indonesia ${ }^{1,2,3}$ \\ \{priyo.subekti@unpad.ac.id $\left.{ }^{1}\right\}$
}

\begin{abstract}
The people of Kei comply the patrilineal kinship system which refers to the father lineage. The essence of the Kei customs is kinship. Kinship in Kei society is understood in a broad sense that covers all dimensions of human life and is not limited to biological kinship. The spirit of kinship and family relationship in Kei, which is bound by customary law, is manifested in the relations of Yanur-Mangohoi, Koi-Maduan, and Teabel. This research uses descriptive method with qualitative data obtained through interview and observation. The informants were chosen purposively with criteria: society leaders and customary figures who understood the customs of Kei people.The kinship of Kei society as described above have some similarities to the basic idea of collective living, the spirit of solidarity and kinship, and prioritizing a brotherhood in the family. The customary agreement conditions all people to help each other and take care of others as their own family. Everyone is tied up in kinship relationships regardless the religion. Social problems which often occur such as disputes between members or teenagers are resolved in familial way. Otherwise, the settlement will be done customarily and this customary law applies to all villages/ohoi in Kei in general.
\end{abstract}

Keywords: Kei, Kinship, Society

\section{Introduction}

The people of Kei are indigenous people in South East of Maluku. They have very strong values of kinship based on lineage blood and marriage. Their views about life values related to issues of marriage that have purpose to have a happy family and long-lasting. To build, develop, and ties the family/kinship relationship which harmonious and guard family/relatives honor, the process of implementing marriage have to set in marching customary in order to avoid an embarrassing breach of which eventually dropped dignity, the family honor, and relatives concerned.

The diversity of the customary law have a very significant impact on some aspects in the custom family law, such as the custom marriage law which includes marriage forms, propose ways, wealth and due to break up of marriage which depends on the society system, based on the custom kinship which includes a personal, related by blood, the bond marriage and ties customary, and the heirs custom which the heirs system[1,2,3,4].

The society of customary law which still strong to defend the kindship principle based on bond offspring blood (genealogical), so the function of marriage is a value living to be able to 
continue offspring, maintain genealogy and raised family concerned. Marriage is one way to improve relations kinship that has been cracked and is a means to approach and conciliation between kinship and so it is with marriage that related with position, wealth, and inheritance problem.

A society who is bound by genealogical line is unity of regular society, who its members attached to a line generation from the same ancestor directly because offspring or indirectly because of marriage bond or customary bond. The smallest unity on the society patrilineal is family or fam, or surname.

The kinship on Kei's is formed by kinship systems that build based on marriage customary tradition. The marriage system is a system based on the father's line (patrilineal). This line of descent happened and caused by family ties that implemented by the strength of the brotherhood relationship between brothers, especially the relationship between siblings. In the system of the indigenous people, it is important to continue lineage (clan): straight or sideways

Kinship systems will affect their marriage customary system because marriage can only be held if the brides have the same caste or social strata. Social strata are very sensitive in Kei. There are 3 levels of strata in Kei namely Mel (nobility), Ren (native), and Iri (low class or servile). Besides, Kei's social strata usually done to the marriage, so marriage can only be held with the same strata. The different of strata is not allowed in marriage. If these violated, there will be sanctioned to one of them is going to remove from their clan.

The custom of marriage is the rules of customary law governing the forms of marriage, ways of purpose, marriage ceremony and marriage breakup in Indonesia. It means that, in customary law, marriage is not only an important occasion for those who are still alive, but marriage is quite a momentous occasion and need people attention because they have to get the blessing of the spirits of the ancestors of both sides.

In a research conducted by Ellyne Dwi Poespasari with a title Outside Marriage Child in Inheritance Viewed from the Legal System of Traditional Kinship Customary suggests outside marital status can be based on three existing kinship system, matrilineal kinship, and parental kinship system. The position of an outside marriage child in customary law is not an heir and not as a biological successor to his father's offspring. The married child has only a relationship with his mother and his mother's relatives. Customary law does not recognize inheritance rights for children outside of marriage [5]. The research describes how strong the customary law regulates the kinship system existing in these indigenous people.

Kei prefers to resolve conflicts using customary law as opposed to a positive law because according to one source the customary law can resolve the conflict in kinship to the root until both parties are satisfied. Because custom is considered to have strong and sacred law force, so as to solve various problems about custom. If customary law is unable to resolve the conflict, then the new society uses the positive law of government. Indigenous people have the same pattern in resolving conflicts in society, i.e., controlling life in society and imposing sanctions if violated so that the recovery becomes very effective[6,7,8,9].

Then Kamaruddin suggested the results of the research show that the model of conflict resolution which is not by the custom institutions in the Acehnese society is not included in conflict resolution by using the theory of mediation settlement in theoretical. Where the process of conflict resolution committed by customary institutions tend to be like the judiciary but the judge who decided the case was taken from the Gampong government or Mukim[10].

From several previous kinds of research on conflict, customary law and kinship, it can be concluded that indigenous peoples tend to overcome conflicts using customary law based on kinship system[11,12,13]. In this case, they are mediated by indigenous leaders who are neutral then sought the base of the problem and its intersection. 
The existence of the customary law of Larvul Ngabal has become the guidance for the Kei indigenous people who are visible and able to resolve various conflicts that occur either in politics, business, misunderstanding, and conflict between religious people. The conflicts that occurred between 1999 and 2000 in the Kei Indigenous Peoples at South East Maluku can be resolved through a kinship approach which is seen from the identity of the clan that is held by the Kei indigenous people by prioritizing the principles contained in the law of Larvul Ngabal enforced in the settlement of the conflict involving the leaders of customary institutions/government.

The kinship system of Kei indigenous people that traces the father lineage, so if marriage held, the wife will follow the husband's clan. Clan is a blood relation, a very strong kinship that encompasses all aspects of Kei society life. Social problems involving inter-religious, territorial and customary conflicts will be resolved on a kinship basis. For example, if there is a social conflict then the solution of the problem will be traced to the history of their kinship is a war whether there is a blood relationship or not, if yes then the problem can be dealt with easily because they are still bound by relatives. The first conflict is solving, Kei people do not either seek religious leaders or are formal figures but trace the family lineage to find their focal points so that conflicts can be resolved peacefully and in a kinship.

Social disaster or social conflict is common in the Kei region. Social conflicts often occur because the character of Kei people is hard and has high self-esteem. To overcome social insecurity in Kei people requires special treatment; it cannot be done hard approach because it will have a bad impact. Conflicts that occur in Kei are usually caused by two things: the boundary of the land and the sister.

This research aims to see how the role of the kinship system in the customary law of Kei people to overcome the conflict that occurs among society. This research uses the descriptive method with qualitative and quantitative data. The method for searching data was using indepth interviews and direct observation.

\section{Result and discussion}

In the marriage order of indigenous peoples, there are unwritten legal principles which in each indigenous society there are different principles and principles of marriage that applicable. In indigenous and tribal peoples whose patrilineal kinship system differs from indigenous peoples whose matrilineal kinship system and so does the parental or bilateral parental. The development, shifts, and changes that occur among indigenous peoples with other indigenous peoples are out of balance.

In customary law people are known three kinship systems[5], namely first, patrilineal kinship system, it is customary society law whose members prefer male lineage rather than female offspring. Therefore the position of boys takes precedence over girls. The position of a son as the successor of his parents (father), while the daughter is prepared to be the son of another person who will strengthen the offspring of others. In a society of patrilineal type, if there is no male offspring, moreover, no offspring, it is called break the descent.

The existence of customary leaders commonly called informal leaders has a huge influence in the customary region. Because the process of becoming an informal leader (customary government) is still guided by the customary law of Larvul Ngabal whose election is based on the offspring system from man side (Patrilineal).

Relates to such rapid changes and tends toward simplifying the ceremony in the big cities. Therefore despite the enactment of Law Number 1 of 1974 on Marriage (herein after referred 
to as Marriage Law) which is national and applicable to all citizens and residents of Indonesia, but the reality in the regions of Indonesia still impose customary marriage.

The Marriage Law does not regulate matters relating to forms of marriage, the way of marriage, customary marriage ceremonies and so on, so that customary law communities still use their own customary marriage law. Ter Haar states marriage is an attempt or a legal event that causes the continuity of the group with its order and is a condition that causes the birth of a new generation that continues the group[14].

\subsection{Kinship System and Conflict Resolution}

Based on the results of research in the field, social conflicts often occur in Kei with various problems ranging such as land boundaries, nudging when the party, and women. Due to a high sense of solidarity and kinship, sometimes individual conflicts can trigger larger conflicts involving among village (Ohoi) or among clans. Conflict can cause a victim of wealth and soul especially if the conflict occurs on a large scale.

In the society, there is often an inevitable conflict because so many individuals or institutions of society between each other have different interests so that these differences of interest will cause a political clash that leads to competition. Conflict is inevitable in Society. Society is seen as a social structure that includes associative and dissociative processes that can only be distinguished analytically. "At the beginning of the emergence of the theory of dialectical conflict, the views of functional, structural theories got doubts from sociologists until eventually creating another alternative to functional theory over basic assumptions $[15,16]$.

The settlement by custom is more effective, and the process is not too long, also the kinship relationship is more tightened. One is to mediate by offering a unique way of dispute resolution. As a process of negotiation, mediation presents a mediator (in this case the king, and the head of Ohoi) acting as facilitator, to help the parties to the agreement reach the agreement received by both parties. Because the process is relatively simple, it takes a short time and the cost can be reduced. In mediation, the parties themselves take an active role in exploring alternatives to establishing the final outcome, with the help of an impartial mediator. The description of the custom settlement in Kei can be seen on the table below:

Table 1.Conflict Resolution in the Society

\begin{tabular}{lll}
\hline Law that used to resolve conflicts that occur in the society & Amount & Percentage \\
\hline Customary Law & 19 & $76 \%$ \\
Religion Law Hukum Agama & 4 & $16 \%$ \\
Positive / Government Law & 15 & $60 \%$ \\
All of the 3 above & 6 & $24 \%$ \\
Other & 0 & $0 \%$ \\
\hline
\end{tabular}

Source: Data Processing 2017

Based on the table above, it appears respondents stated that resolving conflicts that occurred in the society using Customary Law as many as 19 people (76\%), using the Positive / Government Law 15 people (60\%), using Religious Law 5 people (16\%), (Customary Law, Religious Law and Positive / Government Law) as many as 6 people (24\%), and other 1 person $(4 \%)$. 
In general, the dispute resolution process, first resolved by custom. It means by involving the King, the head of Ohoi, and representatives in conflict. After each party gathered, traditional ceremonies were started with a preface. Then discuss the problems that exist to look for the core issues clearly. After the process continues, as the result is getting an agreement and each party feels satisfied and comfortable. The consequences of the results of the talks will be implemented.

The king as the supreme leader of the Ratschap region becomes a mediator in the settlement of the conflict because the position of the King in the Kei society is a highly respected customary position. The position of the King can be seen from the table:

Table 2.Respected Public Figure

\begin{tabular}{lll}
\hline Respected Public Figure & Amount & Percentage \\
\hline King & 24 & $96 \%$ \\
Respected Public Figures Government Officials (Head of & 21 & $84 \%$ \\
Village / Village / Ohoi / Lurah / Camat) & 5 & $20 \%$ \\
Security Apparatus (Army/Police) & 6 & $24 \%$ \\
Clans Chief & 1 & $4 \%$ \\
Tribal Chief & 4 & $16 \%$ \\
Chair of Customary Council & 9 & $36 \%$ \\
Religious Figures & 4 & $16 \%$ \\
Other Government Apparatus (Teacher/ Village Secretary/ & 4 \\
Chair of Bamuskam/ Medical Officer) & 2 & $8 \%$ \\
Other & 2 & \\
\hline
\end{tabular}

Source: Data Processing 2017

Based on the table above, it appears that the respondents who stated the respected public figures are the King as many as 24 people (80\%), respected public figures Government officials (Head of Village / Village / Ohoi / Lurah / Camat) as many as 21 people (84\%), society leaders who are respected by religious figures as many as 9 people (36\%).

Settlement of conflicts in the Kei island tends to take the way of the customary settlement because it is considered more effective and the society better understand the custom. If it can not be resolved by new customary, then it will be processed by law. However, knowledge about criminal law is uneven and the public does not understand the law. So, society strongly upholds customary law (as a very dominant tradition) because it is a habit that has been entrenched roots. To solve this problem, the King and the head of Ohoi play a very important role, it can be described on the table below:

Table 3. Figures/Institution which have a big role in solving the problem in Key nowadays

\begin{tabular}{lll}
\hline $\begin{array}{l}\text { Figures/Institution which have a big role in solving the } \\
\text { problem in society nowadays }\end{array}$ & Amount & Percentage \\
\hline King & 21 & $84 \%$ \\
Respected Public Figures Government Officials (Head of & 21 & $84 \%$
\end{tabular}




\begin{tabular}{|c|c|c|}
\hline $\begin{array}{l}\text { Figures/Institution which have a big role in solving the } \\
\text { problem in society nowadays }\end{array}$ & Amount & Percentage \\
\hline Village / Village / Ohoi / Lurah / Camat) & & \\
\hline Security Apparatus (Army/Police) & 13 & $52 \%$ \\
\hline Clans Chief & 8 & $32 \%$ \\
\hline Tribal Chief & 0 & $0 \%$ \\
\hline $\begin{array}{l}\text { Chair of Customary Council/Society } \\
\text { Organization }\end{array}$ & 3 & $12 \%$ \\
\hline Religious Figures & 2 & $8 \%$ \\
\hline $\begin{array}{l}\text { Other Government Apparatus (Teacher/ Village Secretary/ } \\
\text { Chair of Bamuskam/ Medical Officer) }\end{array}$ & 1 & $4 \%$ \\
\hline Government Institution (Bamuskam) & 0 & $0 \%$ \\
\hline Political Party & 0 & $0 \%$ \\
\hline Non Governmental Organization (NGO) & 0 & $0 \%$ \\
\hline Other & 2 & $8 \%$ \\
\hline
\end{tabular}

Source: Data Processing 2017

Based on the table above, it shows that the respondents who stated that the figures / institutions that play the most important role in solving the problems in the society today are the King and Government Apparatus (Head of Village / Village / Ohoi / Lurah / Camat) 21 people (84\%), Security Apparatus (TNI / POLRI) as many as 13 people (52\%), Clans Chief 8 people (32\%).

Many problems were found to be resolved with criminal law being a peace offer because of customary law. Some of the problems that often occur in the Kei society are land issues, inter-village dispute, persecution, theft, gambling, deception and juvenile delinquency (alcohol).

The Kei society is formed with a high degree of temperamental emotionality, supported by closeness, high family solidarity which, when a family or individual is harassed, all families will be involved. Therefore, conflict resolution approaches to society are somewhat different from violence, always with humanistic communication. If you look at the harsh characteristics of the Kei society, the use of positive law in conflict resolution is not effective, because they strongly uphold the customary law, in this case, is kinship and the solution must also go through customary law.

The problem-solving process is not legally liable if the victim can accept, but if the person does not accept, after the customary process (customary pay) is settled by law. Therefore sometimes the implementation of customs and laws can be contradictory as the process is carried out (custom defeating positive law). The other side of this culture is the suspect's actions can be borne by the other party to take full responsibility for the process and problemsolving.

It is clear that the settlement of a dispute or a criminal offense is the aim of both parties and their families to be better in order to live peacefully and improve the relationships that have been disrupted due to the problems experienced. It is because to bring together an agreement from different characters require a key position to be more effective. 
The values that contained in this culture justify the existence of a law (unwritten) that prevails as a system that is maintained and able to demonstrate its usefulness and effectiveness in solving problems/conflicts that occur, thus minimizing the degree of crime, as it respects the existence of a possible blood relation to society to obey and stay away from evil among others.

\section{Conclusion}

Social conflicts often occur in Kei society whose triggers are land boundary problems, conflicts between young people and women. Conflict resolution more often uses customary law than positive law, because society is an indigenous people who uphold customary law as a regulation that control all aspects of life.

The mediation of conflicts committed by kings and elders using the path of peace, and usually using kinship history, they trace the lineage so that later will meet the point that they are brothers, and the brothers should not conflict and should be peaceful.

Conflict is an index of relationship stability. Given the conflicts among groups, it will increase internal cohesion in-group, further strengthening the sense of brotherhood and kinship between them.

\section{References}

[1] Mahrita A. Lakburlawal, "Kedudukan Suami Dalam Sistem Kekerabatan Masyarakat Adat Ditinjau Dari Perspektif Hak Asasi Manusia," J. Sasi, vol. 20, no. 2, pp. 36-46, 2014.

[2] S. H. Andersen and P. Fallesen, "Family Matters? The effect of kinship care on foster care disruption rates," Child Abus. Negl., vol. 48, pp. 68-79, 2015.

[3] N. Hanaki and S. Kurosu, "Marriage relationships among households in the mid 19th century Tama, Japan. Socioeconomic homogamy, geographical endogamy and kinship networks," Hist. Fam., vol. 15, no. 3, pp. 333-347, 2010.

[4] N. T. Patterson, "Conflicting norms in modern British kinship: Case studies of domestic violence and competition for care in North Wales, 1920-1996," Hist. Fam., vol. 2, no. 1, pp. 1-29, 1997.

[5] Poespasari, "Kedudukan Anak Luar Kawin Dalam Pewarisan Ditinjau Dari Sistem Hukum Kekerabatan Adat," Perspektif, vol. 19, no. 3, pp. 212-222, 2014.

[6] L. A. Bakar, "Revitalisasi Hukum Adat Sebagai Sumber Hukum Dalam Membangun Sistem Hukum Indonesia," J. Din. Huk., vol. 13, no. 2, pp. 319-331, 2013.

[7] N. Susan, "Scenario Building on Law No. 7 of 2012 about Social Conflict Intervention: The Possible Future of Land Conflict Management in Indonesia," in Procedia Environmental Sciences, 2013, vol. 17, no. 7, pp. 870-879.

[8] B. Spruyt, F. Van Droogenbroeck, and J. van Noord, "Conflict thinking: Exploring the social basis of perceiving the world through the lens of social conflict," Soc. Sci. Res., vol. 74, pp. 16-29, 2018.

[9] J. P. Platteau and Z. Wahhaj, Strategic Interactions Between Modern Law and Custom, vol. 2. Elsevier B.V., 2014.

[10] Kamaruddin, "Model Penyelesaian Konflik Di Lembaga Adat," Walisongo J. Penelit. Sos. Keagamaan, vol. 21, no. 1, pp. 39-69, 2013.

[11] C. Boone, "Sons of the Soil Conflict in Africa: Institutional Determinants of Ethnic 
Conflict Over Land," World Dev., vol. 96, pp. 276-293, Aug. 2017.

[12] K. De Pourcq, E. Thomas, B. Arts, A. Vranckx, T. Léon-Sicard, and P. Van Damme, "Understanding and Resolving Conflict Between Local Communities and Conservation Authorities in Colombia," World Dev., vol. 93, pp. 125-135, 2017.

[13] D. M. McKenzie, "The role of mediation in resolving workplace relationship conflict," Int. J. Law Psychiatry, vol. 39, pp. 52-59, Mar. 2015.

[14] T. Haar, Asas-Asas dan Susunan Hukum Adat. Jakarta: Padya Paramita, 1999.

[15] S. Soekanto, Sosiologi Suatu Pengantar. Jakarta: Rajawali Pers, 2009.

[16] S. F. Joireman, "The Mystery of Capital Formation in Sub-Saharan Africa: Women, Property Rights and Customary Law," World Dev., vol. 36, no. 7, pp. 1233-1246, 2008. 